\title{
CHARACTERIZATION OF WASTES FROM SEPTAGE COLLECTION AND TRANSPORT TRUCKS IN THE FEDERAL DISTRICT, BRAZIL
}

\author{
CARACTERIZAÇÃO DOS RESÍDUOS DOS CAMINHÕES LIMPA-FOSSAS NO DISTRITO \\ FEDERAL, BRASIL
}

\author{
Adriane Dias da Silva Lisboa ${ }^{a}$, Yovanka Pérez Ginoris ${ }^{b}$, Marco Antonio Almeida de Souza $^{b}$ \\ ${ }^{a}$ Centro Universitário IESB, ${ }^{b}$ Universidade de Brasília (UnB)
}

adrianedias19@gmail.com,yovanka@unb.br; yovanka.perez@gmail.com,maasouza@unb.br; marcantoniosouza@gmail.com

\section{Abstract}

In the Federal District of Brazil, the cleaning waste from on-site sanitation facilities is transported by septage trucks to sewage treatment plants (STPs) to be treated in conjunction with sewage. This research aimed to characterize the waste from septage trucks that were discharged in the two STPs in Brasilia, Federal District of Brazil. The methodology included the characterization (sampling and laboratory tests) of waste samples collected from septage trucks that discharged waste at the two STPs in Brasília, and the collection of information on the origin of this waste and the frequency of cleaning the on-site sanitation units. Great variability was found in the frequency of cleaning cesspools and septic tanks. The cleaning of the on-site sanitation facilities took place daily in some places and monthly in the remaining sites, and eventually, facilities with annual cleaning were reported. The characteristic that had the lowest variation coefficient was the $\mathrm{pH}$. The presence of large concentrations of oils and greases in the residues of the septage trucks is a major inconvenience. The results obtained contribute to the knowledge of the characteristics of waste from septage trucks, its management and proper treatment.

Keywords: septage; grease trap waste; septage collection and transport truck; oil and grease.

\section{Resumo}

No Distrito Federal, os resíduos da limpeza das instalações de tratamento descentralizado de esgoto são transportados por caminhões limpa-fossas para as estações de tratamento de esgoto (ETEs) para serem tratados em conjunto com o esgoto. Esta pesquisa teve como objetivo caracterizar os resíduos de caminhões limpa-fossas que descarregaram nas duas ETEs de Brasília, Distrito Federal, Brasil. A metodologia incluiu a caracterização (amostragem e exames laboratoriais) de amostras de resíduos coletadas dos caminhões limpa-fossas que descarregaram lodo de fossa nas duas ETEs de Brasília, e a coleta de informações sobre a origem desses resíduos e a frequência de limpeza das unidades de tratamento descentralizado de esgoto. Encontrou-se grande variabilidade nas frequências de limpeza de fossas e tanques sépticos. A limpeza das instalações de tratamento descentralizado de esgotos ocorria diariamente em alguns locais e mensalmente nos demais e, eventualmente, foram registradas instalações com limpeza anual. $\mathrm{O}$ pH foi a característica que apresentou o menor coeficiente de variação. A presença de grandes concentrações de óleos e graxas nos resíduos dos caminhões limpa-fossas é um grande inconveniente. Os resultados obtidos contribuem para o conhecimento das características dos resíduos de caminhões limpa-fossas, sua gestão e tratamento adequado.

Palavras-chave: lodo de fossas e tanques sépticos; resíduos de caixas de gordura; caminhões limpa-fossas; óleos e graxas. 


\section{INTRODUCTION}

Strande, Ronteltap \& Brdjanovic (2014) pointed that the sanitation needs of 2.7 billion people worldwide were served in 2014 by on-site sanitation technologies, and that number is expected to grow to 5 billion people by 2030 . These on-site technologies fulfil sanitation needs not only for rural areas, but around one billion on-site facilities worldwide are in urban areas.

According to SNIS - the Brazilian Sanitation Information System (MDR, 2020), in 2018 Brazil presented an average coverage rate for sewage networks of $53.2 \%$, with this index for urban areas being $60.9 \%$. This shows that almost half of the Brazilian population, on average, is not covered by conventional sewage connections, and this situation is even worse in rural areas. Of this population not served formally by sewage networks, a large part makes use of septic tanks and cesspools for the destination and treatment of their domestic sewage. These decentralized sewage systems require periodic cleaning for their proper functioning, which generates an expressive volume of waste, which has been called "septage".

The sewage systems can be collective or individual, the latter being represented, almost entirely, by septic tanks and cesspools. The periodic cleaning of septic tanks and cesspools should be carried out so as not to impair their functioning. Companies responsible for cleaning septic tanks and cesspools in Brazil are generally hired by the system user and usually clean the grease traps of building systems. For sewage treatment plants (STPs) that receive this type of waste, the presence of oils and greases in the waste from septage trucks has been a problem, mainly due to the impact that fat has on the treatment system. These residues are often disposed of in unsuitable locations such as rivers, streams, and rainwater culverts, creating yet another health and environmental problem.

The septage, identified in the present work as "waste from septage trucks", does not only contain the solid fraction itself, but also the liquid and supernatant fraction present in the septic tank or cesspool. As septage trucks collect waste from several different on-site sanitation systems, the waste collected and transported by these trucks is not pure septage. For this reason, there is a great confusion of the terms used to describe this type of material. It is possible to keep the name "septage" as long as it is clear that this residue has its own characteristics, and it is not exactly septage.
The National Survey on Basic Sanitation (PNSB) recorded in 2008 that, in the Federal District of Brazil, the rate of service with sewage collection network was $86.3 \%$ (IBGE, 2008). In 2018 , the rate of service with sewage collection was $89.28 \%$ in the Federal District (CAESB, 2020). According to PDAD-2013/2014 - District Household Sample Survey - in 2013, $85.95 \%$ of the conventional sewage systems in the Federal District were serviced, with 32,495 "rudimentary cesspools" and 82,589 "septic cesspools" being recorded (CODEPLAN, 2014).

In 2015, in the Federal District of Brazil, the conventional sewage network covered $85.46 \%$ of the population, and the rest not covered was served by septic tanks (10.33\%), and rudimentary cesspools $(4.10 \%)$, with a small percentage $(0.11 \%)$ that launched sewage in the ground surface or in other ways (CODEPLAN, 2020). The most distant regions and rural areas use septic tanks or cesspools due to the absence of a sewage collection network.

In the Federal District, the reception of waste from septage trucks by STPs was the subject of an agreement between the Urban Cleaning Service (SLU), the Federal District Environmental Sanitation Company (CAESB), the water and sanitation regulatory agency (ADASA), and the environmental agency (IBRAM-SEDUMA), and it was monitored by the Public Ministry. Under this agreement, CAESB is receiving and treating the waste transported by the companies responsible for cleaning septic tanks and cesspools. The SLU is responsible for receiving the solid waste produced (dry sludge) in landfills, and the rest (ADASA, IBRAM-SEDUMA) are responsible for the control, inspection, and management of the system (DA SILVA, 2014).

Upon receiving wastes from septic tanks and cesspools at STPs, CAESB admits oil and grease concentration values of up to $1,080 \mathrm{mg} \cdot \mathrm{L}^{-1}$ at its septage receiving plant. Initially, no fee is charged for unloading septage at the CAESB septage receiving plant. However, samples are collected and sent for analysis of oils and greases, and if the value is greater than $1,080 \mathrm{mg} \cdot \mathrm{L}^{-1}$, the company responsible for cleaning septic tanks and cesspools is notified and must pay the disposal fee, as in this case, the waste is considered "high in fat". In order to discharge waste from septage trucks at sewage treatment plants authorized to receive these types of waste, the cleaning company must obtain authorization from CAESB and undergo courses and training (DA SILVA, 2014). 
Knowledge of the physical and chemical characteristics of septage is important for the selection of treatment methods and techniques alone or in conjunction with sewage. The objective of this research was to increase and improve the knowledge of the most important physical and chemical characteristics of waste from septage trucks in the Federal District. This work also produced data on the origin of these residues, on the frequency of cleaning of the on-site treatment systems that generated them, and on some of their organoleptic characteristics. It brings a contribution to the knowledge of the characteristics of these residues, so that they can receive the appropriate treatment, either isolated or combined with sewage.

\section{PREVIOUS WORKS}

Rodrigues et al. (2009) characterized the septage in the Federal District by collecting samples called "random", whose procedure consisted of sampling septage trucks that unloaded their contents at the South Brasilia Sewage Treatment Plant, and samples called "in situ" that consisted of sampling directly from trucks that were used to clean pre-selected septic tanks and cesspools. Samples "in situ" were carried out in two stages with an interval of six months. In this research, the samples were examined for $\mathrm{pH}$, alkalinity, COD, ammoniacal nitrogen, TKN, series of solids, and coliforms. The measurement of oils and greases was not performed, however. The average values found were: $\mathrm{pH}$ between 6.8 and 7.1; alkalinity between 127 and $662 \mathrm{mg}^{-1} \mathrm{CaCO}_{3}$; COD between 1,281 and 9,493 mg. $\mathrm{L}^{-1}$; ammoniacal nitrogen between 51 and $138 \mathrm{mg} \mathrm{N}$ $\mathrm{NH}_{3} \mathrm{~L}^{-1}$; TKN between 160 and $369 \mathrm{mg} \mathrm{N}^{-\mathrm{L}^{-1}}$; total phosphorus between 12 and $29 \mathrm{mg} \mathrm{PO}_{4} . \mathrm{L}^{-1}$; total solids between 6,514 and $10,214 \mathrm{mg} \cdot \mathrm{L}^{-1}$; total volatile solids between 4,520 and $7,368{\mathrm{mg} . \mathrm{L}^{-1} \text {; }}^{-}$ total suspended solids between 5,916 and 12,460 mg. $\mathrm{L}^{-1}$; volatile suspended solids between 4,153 and $8,730 \mathrm{mg}^{\mathrm{L}} \mathrm{L}^{-1}$; and settleable solids between 70 and $297 \mathrm{~mL} . \mathrm{L}^{-1}$. The density of thermotolerant coliforms, in twelve samples analysed ranged from $7.5 \mathrm{E}+04 \mathrm{NMP} .100 \mathrm{~mL}^{-1}$ to values above $2.4 \mathrm{E}+07$ NMP. $100 \mathrm{~mL}^{-1}(67 \%$ of the samples showed values above $2.4 \mathrm{E}+07 \mathrm{NMP} .100 \mathrm{~mL}^{-1}$ ). Table 1 shows the results found by Rodrigues et al. (2009) compiled and presented by Ingunza et al. (2009).

In the research presented by Rodrigues et al. (2009), the mean septage density value of the various septage samples from cesspools and septic tanks was equal to $1042.5 \mathrm{~kg} \cdot \mathrm{m}^{-3}$, with a minimum measured of $580 \mathrm{~kg} \cdot \mathrm{m}^{-3}$ and a maximum of $1,459 \mathrm{~kg} \cdot \mathrm{m}^{-3}$.

Research carried out in Brazil with septage showed great variation in the composition of this residue. For example, the average values ranged between 12,880 and $49,593 \mathrm{mg} . \mathrm{L}^{-1}$ for Total Solids; between 3,413 and 29,685 mg. $\mathrm{L}^{-1}$ for Total Volatile Solids; between 2,064 and 37,731 mg. $\mathrm{L}^{-1}$ for Total Suspended Solids; between 1,087 and 5,019 mg.L1 for Volatile Suspended Solids; between 1,863 and $11,424 \mathrm{mg} \cdot \mathrm{L}^{-1}$ for BOD; between 6,199 and 23,835 $\mathrm{mg} . \mathrm{L}^{-1}$ for COD; between 58 and $768 \mathrm{mg}^{-\mathrm{L}^{-1}}$ for Ammonia; between 18 and $112 \mathrm{mg} \cdot \mathrm{L}^{-1}$ for Total Phosphorus; and between 327 and 1,588 mg. $\mathrm{L}^{-1}$ for oils and grease (INGUNZA et al., 2009).

Ramos (2014) examined six waste samples from septage trucks in the city of Cuiabá, Mato Grosso State, Brazil, collected at fifteen-day intervals and obtained the results shown in Table 2.

Andrade (2015) collected and examined samples of waste from septage trucks in the region of Belo Horizonte city, State of Minas Gerais, Brazil, and surroundings, and found the results shown in Table 3.

Santos (2009) performed the septage characterization in the city of Natal, State of Rio Grande do Norte, Brazil. With a special column sampler, samples were collected from the interior of 14 septic tanks and 10 cesspools in neighborhoods of Natal. The measurements performed in the 24 systems resulted in medians for temperature, $\mathrm{pH}$, electrical conductivity, oils and greases, total solids, and total suspended and settleable solids of $28.0{ }^{\circ} \mathrm{C} ; 6.95 ; 882 \mathrm{mS} \mathrm{cm}^{-1}$; $75.2 \mathrm{mg} . \mathrm{L}^{-1} ; 10,169 \mathrm{mg} \cdot \mathrm{L}^{-1} ; 6,509 \mathrm{mg} \cdot \mathrm{L}^{-1}$, and 175 $\mathrm{mL} . \mathrm{L}^{-1}$, respectively; $111.0 \mathrm{mgN}^{-1} \mathrm{~L}^{-1}$ for ammonia, $130.5 \mathrm{mgN}^{-1}$ for organic nitrogen, $0.2 \mathrm{mgN}^{-L^{-1}}$ for nitrite, $0.4 \mathrm{mg} . \mathrm{L}^{-1}$ for nitrate; $8,935 \mathrm{mgO}_{2} . \mathrm{L}^{-1}$ for COD, $29.2 \mathrm{mgP}^{-\mathrm{L}^{-1}}$ for total phosphorus; $9.95 \mathrm{E}+$ 06 UFC. $100 \mathrm{~mL}^{-1}$ thermotolerant coliforms and 9.2 eggs. $L^{-1}$ helminth eggs with a maximum concentration of 688 eggs. $\mathrm{L}^{-1}$ and a minimum of 0 eggs. $L^{-1}$. The variability of physical, chemical, and biological characteristics was considered excessively high. A statistically significant difference was detected only for organic nitrogen and TKN between septic tanks and cesspools. The concentrations of the fractions of solids, COD, Organic Nitrogen, and Total Phosphorus were reduced after six months of the first cleaning of the septic tanks and cesspools. There was no statistically significant difference between the 24 
septage samples collected directly from septic tanks and cesspools and 42 septage samples collected directly from trucks.

Borges (2009) carried out the physical and chemical characterization of the septage produced in the cities of São Carlos and Campinas, in the state of São Paulo, Brazil. In São Carlos, in situ collection was carried out in eight septic tanks using an Ekman Dredge bottom sampler, and direct collection in the discharge of septage trucks that exhausted the same facilities. Due to the bottom sampler used, which collected only the bottom sludge, Borges (2009) concluded that the samples in situ had higher concentrations than the samples from the septage trucks. The significant presence of oils and greases in the septage of the two cities was evidenced, with median values of $375 \mathrm{mg} . \mathrm{L}^{-1}$ in São Carlos and $158 \mathrm{mg} \cdot \mathrm{L}^{-1}$ in Campinas. In situ septage sampling was performed in the city of São Carlos twice in the same facility, the second time six months after the first, and it was identified that the frequency of cleaning septic tanks and cesspools is an important determinant of septage characteristics (a COD of up to 2.4 times greater was detected in the septage of the first sample).

Table 1: Random and in situ characterization of septage in the Federal District of Brazil.

\begin{tabular}{|c|c|c|c|c|c|c|c|c|c|c|c|}
\hline & $\frac{T}{Q}$ & 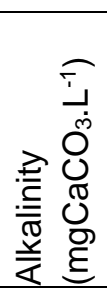 & 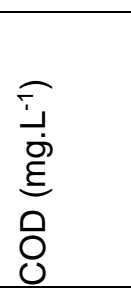 & 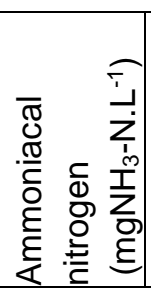 & 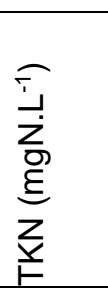 & 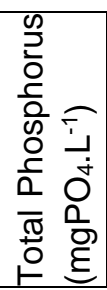 & 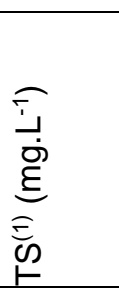 & 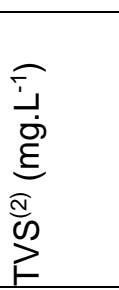 & 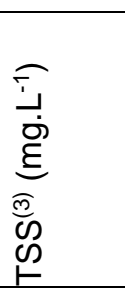 & 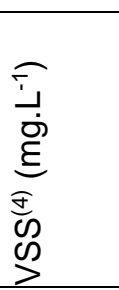 & 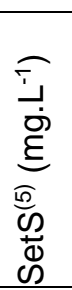 \\
\hline \multicolumn{12}{|c|}{ Random characterization } \\
\hline$N^{(6)}$ & 15 & 15 & 13 & 13 & 11 & 14 & 8 & 7 & 8 & 7 & 15 \\
\hline Minimum & 5.9 & 79 & 108 & 11 & 53 & 0 & 715 & 133 & 574 & 257 & 0 \\
\hline Maximum & 7.9 & 1,450 & 6,932 & 98 & 473 & 52 & 45,555 & 31,097 & 35,853 & 24,047 & 450 \\
\hline Mean & 7.1 & 390 & 1,281 & 51 & 160 & 14 & 10,214 & 7,368 & 6,395 & 4,996 & 70 \\
\hline Median & 7.1 & 271 & 487 & 54 & 90 & 8 & 1,504 & 1,263 & 1,010 & 1,015 & 4 \\
\hline $\mathrm{SD}^{(7)}$ & 0.6 & 371 & 1,911 & 26 & 149 & 16 & 16,274 & 11,497 & 12,125 & 8,600 & 129 \\
\hline $\mathrm{CV}^{(8)}$ & 8.0 & 95 & 149 & 51 & 93 & 118 & 159 & 156 & 190 & 172 & 185 \\
\hline \multicolumn{12}{|c|}{ In-situ characterization of septage for the first collection } \\
\hline $\mathrm{N}$ & 9 & 9 & 8 & 8 & 9 & 7 & 8 & 8 & 7 & 7 & 9 \\
\hline Minimum & 5.5 & 250 & 5,030 & 37 & 135 & 6 & 2,955 & 970 & 2,453 & 247 & 100 \\
\hline Maximum & 7.8 & 1,650 & 13,203 & 508 & 1,020 & 71 & 14,110 & 9,933 & 9,745 & 8,106 & 775 \\
\hline Mean & 6.8 & 662 & 9,384 & 138 & 369 & 29 & 7,213 & 4,694 & 5,916 & 4,153 & 297 \\
\hline Median & 7.0 & 590 & 9,131 & 97 & 338 & 31 & 7,330 & 4,347 & 4,313 & 2,787 & 250 \\
\hline $\mathrm{SD}^{(7)}$ & 0.8 & 424 & 2,723 & 155 & 266 & 22 & 4,066 & 3,055 & 3,228 & 3,131 & 214 \\
\hline $\mathrm{CV}^{(8)}$ & 11.8 & 64 & 29 & 113 & 72 & 77 & 56 & 65 & 55 & 75 & 72 \\
\hline
\end{tabular}

In-situ characterization of septage for the second collection (after 6 months)

\begin{tabular}{l|l|l|l|l|l|l|l|l|l|l|l}
\hline $\mathrm{N}$ & 6 & 6 & 6 & 4 & 4 & 6 & 5 & 5 & 2 & 2 & 6 \\
\hline Minimum & 5.9 & 61 & 2,757 & 44 & 98 & 2 & 730 & 620 & 9,310 & 6,180 & 14 \\
\hline Maximum & 8.6 & 214 & 16,160 & 80 & 345 & 34 & 16,540 & 11,945 & 15,610 & 11,280 & 450 \\
\hline Mean & 6.9 & 127 & 9,493 & 62 & 184 & 12 & 6,514 & 4,520 & 12,460 & 8,730 & 142 \\
\hline Median & 6.6 & 118 & 7,963 & 62 & 146 & 9 & 3,470 & 3,070 & 12,460 & 8,730 & 95 \\
\hline $\mathrm{SD}^{(7)}$ & 0.9 & 56 & 5,232 & 16 & 117 & 12 & 6,535 & 4,576 & 4,455 & 3,606 & 156 \\
\hline $\mathrm{CV}^{(8)}$ & 13.7 & 44 & 55 & 26 & 64 & 101 & 100 & 101 & 36 & 41 & 110
\end{tabular}

(1) TS: Total Solids; (2) TVS: Total Volatile Solids; (3) TSS: Total Suspended Solids; (4) VSS: Volatile Suspended Solids; ${ }^{(5)}$ SetS: Settleable Solids; ${ }^{(6)} \mathrm{N}$ : number of data; ${ }^{7)}$ SD: Standard Deviation; ${ }^{(8)} \mathrm{CV}$ : Coefficient of Variation.

Source: Ingunza et al. (2009), adapted. 
Table 2: Descriptive statistics of the septage characteristics in Cuiabá City, State of Mato Grosso, Brazil.

\begin{tabular}{|c|c|c|c|c|c|c|c|}
\hline \multirow{2}{*}{$\begin{array}{c}\text { Septage } \\
\text { Characteristics }\end{array}$} & \multicolumn{7}{|c|}{ Parameters of descriptive statistics } \\
\hline & $N^{(1)}$ & Mean & Median & Minimum & Maximum & $\begin{array}{l}\text { Standard } \\
\text { Deviation }\end{array}$ & $\begin{array}{c}\text { Variation } \\
\text { Coefficient } \\
(\%)\end{array}$ \\
\hline Temperature $\left({ }^{\circ} \mathrm{C}\right)$ & 6 & 27.3 & 27.7 & 25.0 & 29.0 & 1.5 & 5.4 \\
\hline $\mathrm{pH}$ & 6 & 7.6 & 8.5 & 6.5 & 9.5 & 1.0 & 13.2 \\
\hline $\begin{array}{l}\text { Alkalinity } \\
\left(\mathrm{mgCaCO}_{3} \mathrm{~L}^{-1}\right)\end{array}$ & 6 & 173 & 157 & 137 & 285 & 56 & 32.5 \\
\hline $\mathrm{BOD}_{5}\left(\mathrm{mg} \cdot \mathrm{L}^{-1}\right)$ & 6 & 1,142 & 790 & 193 & 3,553 & 1,248 & 109 \\
\hline $\operatorname{COD}\left(m g \cdot L^{-1}\right)$ & 6 & 3,224 & 2,561 & 311 & 7,600 & 2,943 & 91 \\
\hline $\begin{array}{l}\text { Total phosphorus } \\
\left(\mathrm{mgP} . \mathrm{L}^{-1}\right)\end{array}$ & 6 & 3.0 & 3.4 & 2.5 & 3.9 & 0.6 & 20 \\
\hline TKN (mgN.L-1) & 6 & 270 & 251 & 118 & 398 & 117 & 43 \\
\hline Total Solids $\left(\mathrm{mg} \cdot \mathrm{L}^{-1}\right)$ & 6 & 451.6 & 467.1 & 274.6 & 621.7 & 135.4 & 30 \\
\hline $\begin{array}{l}\text { Total volatile solids } \\
\left(\mathrm{mg}^{\left.-\mathrm{L}^{-1}\right)}\right.\end{array}$ & 6 & 175.8 & 186.8 & 82.3 & 248.7 & 61.9 & 35 \\
\hline $\begin{array}{l}\text { Settleable Solids } \\
\left(m L . L^{-1}\right)\end{array}$ & 6 & 7.1 & 7.1 & 6.0 & 8.2 & 0.81 & 11.4 \\
\hline
\end{tabular}

(1) $\mathrm{N}$ : number of data.

Source: Ramos (2014), adapted.

Table 3: Characteristics of septage in the region of Belo Horizonte city and its surroundings, State of Minas Gerais, Brazil.

\begin{tabular}{|c|c|c|c|c|c|c|c|}
\hline \multirow{2}{*}{$\begin{array}{c}\text { Septage } \\
\text { Characteristics }\end{array}$} & \multicolumn{7}{|c|}{ Parameters of descriptive statistics } \\
\hline & $\mathrm{N}^{(1)}$ & Mean & Median & Minimum & Maximum & $\begin{array}{l}\text { Standard } \\
\text { Deviation }\end{array}$ & $\begin{array}{c}\text { Variation } \\
\text { Coefficient } \\
(\%)\end{array}$ \\
\hline Temperature $\left({ }^{\circ} \mathrm{C}\right)$ & 41 & 27.0 & 27.1 & 21.3 & 32.8 & 2.5 & 9.26 \\
\hline $\mathrm{pH}$ & 41 & 7.1 & 7.3 & 5.2 & 8.7 & 0.9 & 12.68 \\
\hline $\mathrm{OD}\left(\mathrm{mg} \cdot \mathrm{L}^{-1}\right)$ & 40 & 1.1 & 0.5 & 0.1 & 4.6 & 1.2 & 109.09 \\
\hline $\mathrm{BOD}_{5}\left(\mathrm{mg} \cdot \mathrm{L}^{-1}\right)$ & 34 & 2,649 & 1,074 & 136 & 18,420 & 4,355 & 164.78 \\
\hline $\mathrm{COD}\left(\mathrm{mg} \cdot \mathrm{L}^{-1}\right)$ & 43 & 5,838 & 2,937 & 174 & 31,400 & 7,284 & 124.77 \\
\hline $\mathrm{N}-\mathrm{NH}_{4}+\left(\mathrm{mgN}_{\mathrm{L}} \mathrm{L}^{-1}\right)$ & 33 & 82 & 82 & 3 & 201 & 52 & 63.41 \\
\hline TKN (mgN.L-1) & 35 & 109 & 88 & 5 & 564 & 103 & 94.49 \\
\hline Total Solids (mg.L-1) & 43 & 6,373 & 2,349 & 583 & 61,391 & 10,358 & 162.53 \\
\hline Total volatile solids $\left(\mathrm{mg}^{\mathrm{L} \mathrm{L}^{-1}}\right)$ & 42 & 4,103 & 1,133 & 9 & 58,495 & 9,440 & 230.07 \\
\hline $\begin{array}{l}\text { Coliformes totais } \\
\text { (NMP.100mL) }\end{array}$ & 23 & $1,3 \times 10^{11}$ & $9,8 \times 10^{10}$ & $2,5 \times 10^{9}$ & $2,4 \times 10^{11}$ & $1,0 \times 10^{11}$ & 76.92 \\
\hline E. coli (NMP.100mL) & 23 & $2,1 \times 10^{10}$ & $3,6 \times 10^{9}$ & $4,1 \times 10^{8}$ & $2,4 \times 10^{11}$ & $5,2 \times 10^{10}$ & 247.62 \\
\hline
\end{tabular}

(1) $\mathrm{N}$ : number of data.

Source: Andrade (2015), adapted.

Krithika et al. (2017) studied the septage of the city of Chennay, in India, and found high variability in its characteristics, which is not only dependent on seasons and locations but also reliant on the number of households, cleaning frequency, pumping rate, vacuum suction ratio, source, and other factors. Average concentrations of total solids were $2185 \pm 1070$ and $3555 \pm 2935$ 
mg. $\mathrm{L}^{-1}$ during summer and winter, respectively. Total chemical oxygen demands (COD) were 905 $\pm 603 \mathrm{mg} \cdot \mathrm{L}^{-1}$ (summer) and $1460 \pm 1295 \mathrm{mg} \cdot \mathrm{L}^{-1}$ (winter). Krithika et al. (2017) also showed that septage was rich in nutrients, such as total nitrogen (4 - 500 mg. $\left.\mathrm{L}^{-1}\right)$, ammoniacal nitrogen (2 - 129 $\left.\mathrm{mg} \cdot \mathrm{L}^{-1}\right)$, total phosphate $\left(5-236 \mathrm{mg} \cdot \mathrm{L}^{-1}\right)$, and heavy metals, such as copper, zinc, lead, and manganese. The major source of septage in Chennay city was from individual houses $(42 \%)$, followed by apartments $(26 \%)$, institutions (13\%), industries $(10 \%)$, hotels $(8 \%)$, and hospital $(1 \%)$. The frequency of cleaning the on-site facilities ranged from daily to once a year, but daily and once a month cleaning was the most common.

The septage characterization studies have verified that, except for $\mathrm{pH}$ and temperature parameters, the general characteristics of these residues present high variability, non-normal distribution and high concentrations of its components when compared to domestic sewage. Due to this fact, researchers on the topic prefer to rely on the median values instead of the average, and alternatively indicate only the range of variation of the concentrations.

In fact, research has shown the variability of septage characteristics, whether collected directly from the system (septic tank or cesspool) or in septage trucks (MENESES et al., 2001; BLUNIER et al., 2004; ROCHA \& SANT'ANNA, 2005; LEITE et al., 2006; SANTOS, 2009; RATIS, 2009; BORGES, 2009; HALALSHEH et al., 2011; BASSAN et al., 2013). Several factors that cause this great variability in the characteristics of the septage are pointed out, such as the range of different on-site technologies used, the way in which the system is used, the storage duration (filling rates and collection frequencies), inflow and infiltration, and the local climate (STRANDE, RONTELTAP \& BRDJANOVIC, 2014).

Despite the great variability of septage characteristics drawn on information taken from several sources by Lopez-Vazquez et al. (2014), Tayler (2018) reached the following conclusions, referring specifically to faecal sludge: (1) fresh faecal sludge contains a high proportion of biodegradable material, an average of $84 \%$ biodegradable COD, of which nearly one-fifth is "readily biodegradable" and the remainder "slowly biodegradable"; (2) digested faecal sludge contains a much higher proportion of nonbiodegradable material, an average of $56 \%$, of which almost $85 \%$ is particulate and hence potentially settleable; and (3) the biodegradable proportion of digested faecal sludge, while smaller than that of faecal sludge, is still likely to be significant, its average is $44 \%$, of which around $30 \%$ is readily biodegradable.

An observation should be made about the term faecal sludge and what the most accepted concept is, despite the great divergence among researchers on the subject. Faecal sludge can be understood as the mixture of human excreta, water, and solid wastes (such as toilet paper and menstrual hygiene materials) that gets collected in on-site sanitation systems, while septage is a type of faecal sludge and refers to the partially digested faecal solids that accumulate in septic tanks (NARAYANA, 2020; TAYLER, 2018; STRANDE, RONTELTAP \& BRDJANOVIC, 2014).

\section{MATERIALS AND METHODS}

The methodology of this work included the characterization of waste samples collected from septage trucks that arrived to unload at the sewage treatment plants (STPs) in Brasília, Federal District - North Brasilia STP and South Brasilia STP.

The operators of septage trucks declared the origin of the waste at the time they unloaded at the STPs. At the same time, the researcher interviewed septage truck operators and recorded the origin and frequency of cleaning of the on-site sewage treatment units in a specific form.

Specifically for this research, a "Waste Generator Registration Form" was elaborated and applied, in which each operator declared, and the researcher wrote down the following data: origin of the waste; date of collection of the waste; frequency of collection or cleaning of the on-site sewage treatment unit; nominal septage truck capacity; truck unload time; volume of waste discharged; and organoleptic characteristics of the waste (colour, odour, appearance). Each truck waste had its $\mathrm{pH}$ measured at the time of its discharge.

When arriving at the disposal site, the septage truck operator was required to present the waste disposal authorization and the "Waste Generator Registration Form" duly completed, in which there was an indication of the origin of the waste (residential or commercial septic tank, chemical toilet, greasy residue, and others).

For the collection of waste samples both at the North and South Brasilia STPs, septage trucks were chosen at random, as long as operators declared their waste as originating from septic tanks and cesspools. 
During truck unloads at the North Brasilia STP, three 50-liter aliquots of sample were collected directly from the truck's hose, one at the beginning, one in the middle, and one at the end of the unloading, which lasted an average of 10 minutes. The aliquots were stored in a fiberglass tank and four litres of sample were collected after homogenization and sent for analysis. To guarantee the absence of coarse solids in the samples, a wire screen, with a $1.5 \mathrm{~cm}$ opening, was installed over the fiberglass tank.

At the South Brasilia STP, samples were collected while the septage truck was discharging its waste into the receiving tank of the pilot plant. More precisely. the collections were made exactly at the point after the waste passed through the $0.45 \mathrm{~m} \times 0.45 \mathrm{~m}$ "box" type grid. This "box" type grid was built with $3 / 8$-inch steel bars and $2 \mathrm{~cm}$ apart. It was necessary to collect at this point, because there is often the presence of coarse solids that can eventually disturb the performance of the tests and cause inaccuracies in the measurements. Samples were collected from all trucks unloading during the operation and monitoring of the Pilot Plant.

As with the North Brasilia STP, samples from the South Brasilia STP were collected at the beginning, middle, and end of unloading, considering the unloading time of each truck (5 to 15 minutes). However, it is noteworthy that the final samples consisted of the homogenizing of waste samples from septage trucks unloading at each operation of the pilot plant. In each operation of the pilot plant, an average of five trucks were unloaded, and samples were collected in nine operations. In this way, samples composed of each septage truck were collected, and, at the end of each operation, there was around 30 liters of each final sample. After homogenizing the content of the composite sample, a 1-liter aliquot was collected for the analysis of oils and greases in a glass bottle and 5 liters for the other analyses, that is, a total of 6 liters of samples were sent to the laboratory.

The septage samples eventually mixed with residues from grease traps were also characterized. In six campaigns to monitor the pilot plant, waste with these characteristics was received (septage combined with grease trap waste). Residue samples from septic tanks, cesspools, and grease traps were collected from all trucks that unloaded their contents at the pilot pretreatment and conditioning plant for septage truck waste at the South Brasilia STP. The mixture between septage and waste from grease traps was made following the distribution of trucks in the unloading queue, trying to reproduce the real situation.

The physical and chemical characterization of the waste was carried out as recommended by the Standard Methods for the Examination of Water and Wastewater (APHA, 2005). The following characteristics of the residues were examined: $\mathrm{pH}$, alkalinity, electrical conductivity, chlorides, total solids, total suspended solids, volatile and fixed solids, settleable solids, COD, Total Kjeldahl Nitrogen, Ammoniacal Nitrogen, Total Phosphorus, and Oils and Greases.

The results of the tests performed on the residues were construed using descriptive statistics to obtain maximum and minimum values, central tendency (mean, median), and dispersion values (standard deviation, coefficient of variation, and quartiles). For this, the software STATISTICA version Trial12 (TIBCO, 2020) was used.

\section{RESULTS AND DISCUSSION}

\subsection{Characterization of waste from septage trucks by their origin and the frequency of cleaning of septic tanks and cesspools}

From the records or questionnaires with the information declared by the truck operators, it was possible to characterize the waste by its origin and frequency of cleaning of the cesspools and septic tanks, as shown in Figures 1, 2, and 3. These data were obtained by filling in the "Waste Generator Registration Form", designed to be used in the field.

Figure 1 shows the origin of waste samples from septage trucks collected at the North Brasilia STP, as declared by the operators.

It was observed that $70 \%$ of the samples collected were originated from condominiums, mostly residential, $20 \%$ divided equitably between homes and restaurants and $10 \%$ divided equitably between companies and bakeries. The frequency of septic tanks and cesspools cleaning ranged from daily to annual, with weekly being the most frequent. Note that the cleaning frequency is related to the number of times the operator exhausts the septic tank or cesspool where the service was contracted. In addition, septage trucks' operators that are authorized to unload at the STPS in the Federal District must obtain this information from customers, as it is necessary to deliver the registration of the waste generator upon arrival at the STPs.

Figure 2 shows the origin of the waste from 
septage trucks that unloaded at the South Brasilia STP, as declared by the trucks' operators.

It can be seen from Figure 2 that of the declared origin of the septage, $75 \%$ were from residential origin, $13 \%$ were from commercial origin, $5 \%$ of the trucks contained a mix of septage from homes and businesses, and 7\% were from construction sites and party houses.

\section{Figure 1: Declared origin of waste from the North Brasilia STP septage trucks.}

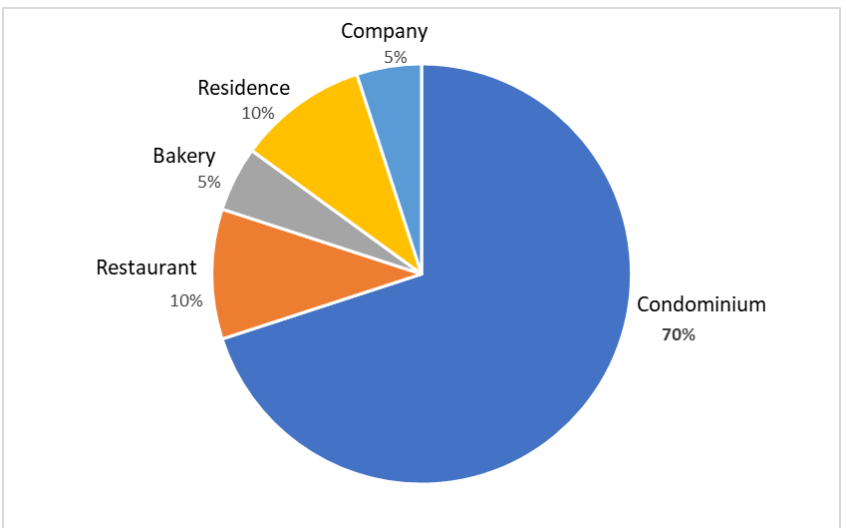

Source: the authors.

Figure 2: Declared origin of waste from the South Brasilia STP septage trucks.

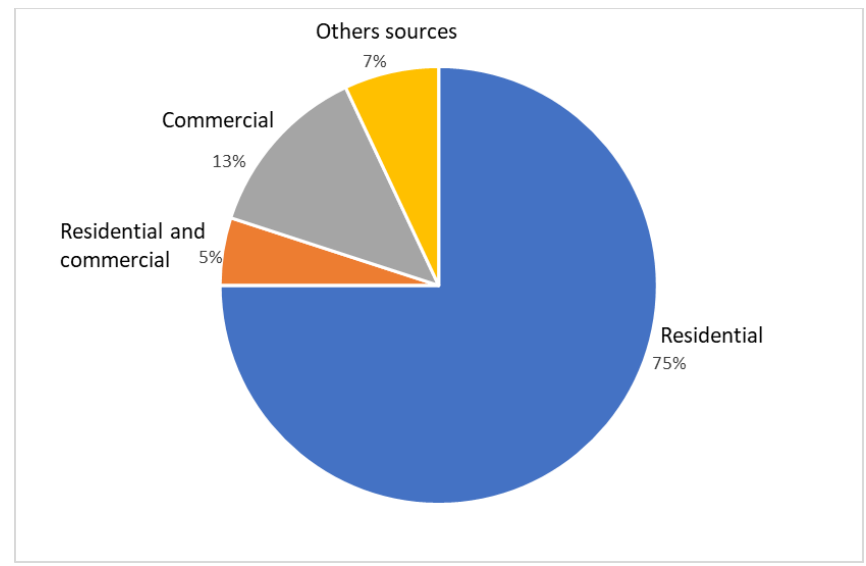

Source: the authors.

Regarding the frequency of cleaning septic tanks and cesspools related to the waste discharged at the South Brasilia STP, it was possible to verify a great variability in the declared times. Figure 3 presents the graph with these results.

It was found that of the forty-one septage trucks registered unloading at the South Brasilia STP, nine trucks transported waste from septic tanks and cesspools cleaned daily, four-monthly, three-weekly, and three that were cleaned three times a week. It has been observed that few trucks have septage with more than one year of accumulation, and that in fact many of these exhausted on-site sanitation facilities are functioning only as holding tanks or passage tanks. In general, it was observed that the most frequent source of waste received in the two STPs was the residential one, and that the largest number of cleaning of the on-site sewage treatment equipment was carried out with the frequency between daily and weekly. Three explanations can be generically given for what has been observed: (1) the septic tanks were not connected to an effluent absorption system on the ground; (2) the local soil does not have sufficient permeability for absorption; or (3) the local water table level does not allow absorption into the ground. In all options, 
it is evident that there is an inadequacy of the local sanitation solution accompanied by great technical and economic inefficiency. Herein lies an important contribution of this research, which is to show the need for a survey of decentralized sewage systems in the Federal District to know specifically the reasons why this problem is occurring and its possible solution.

The majority of the septage was slightly grey in color, characterized as a recent or fresh septage, which is related to the high frequency of cleaning of the on-site sewage treatment systems that was observed.

\section{Figure 3: Frequencies of cleaning septic tanks and cesspools declared by} septage truck operators unloading at the South Brasilia STP.

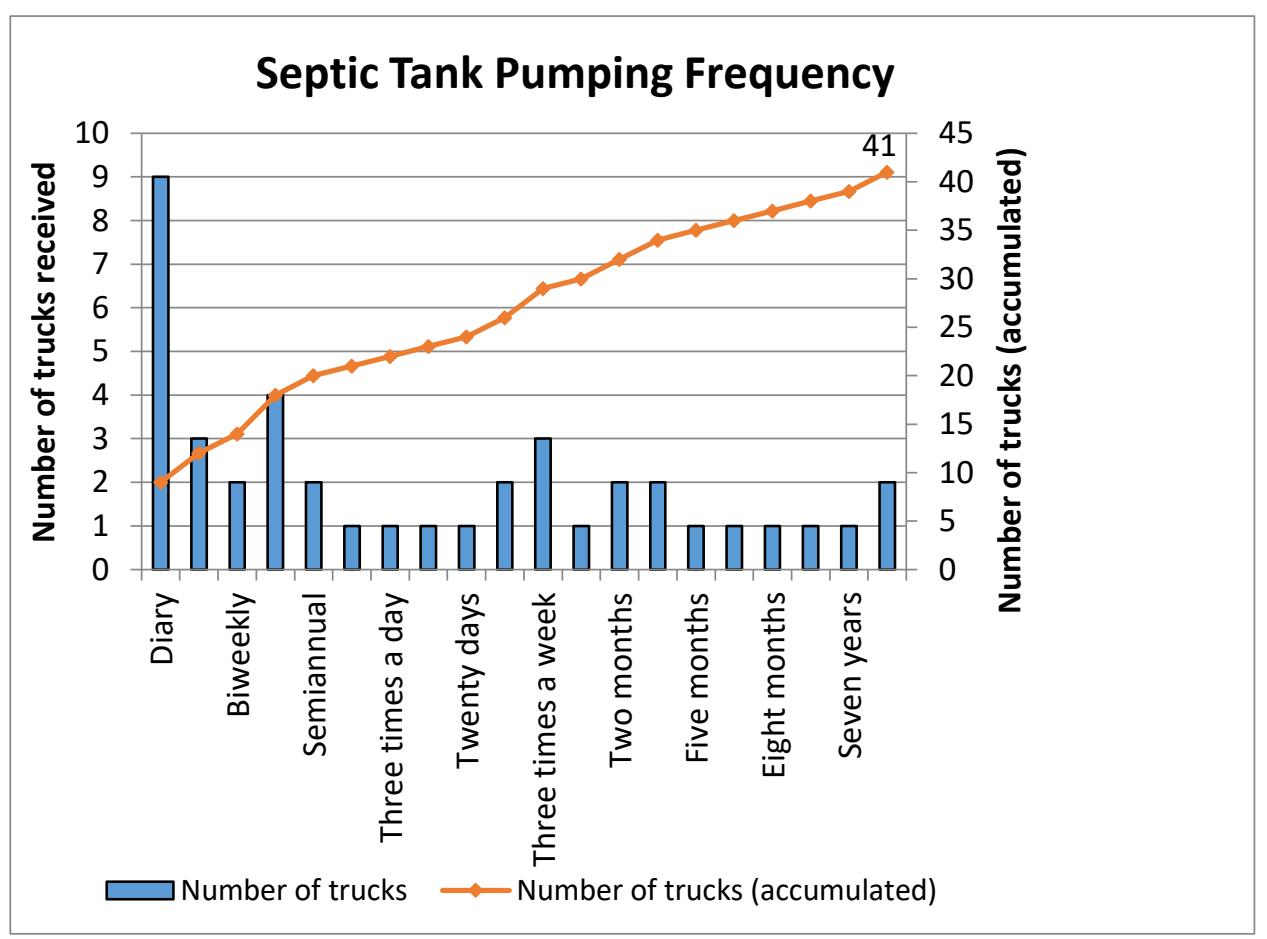

Source: the authors.

\subsection{Physical and chemical characterization of septage truck waste}

Table 4 presents the descriptive statistics of the results obtained in the physical and chemical characterization of the waste samples from septage trucks collected in the two STPs in Brasília.

The $\mathrm{pH}$ was the characteristic that presented the lowest variation coefficient, with an interval between 5.9 and 7.9. A network research carried out in Brazil (ANDREOLI, 2009) showed that the $\mathrm{pH}$ of septage of exclusively domestic origin has a value close to 7.0 , and if the $\mathrm{pH}$ is below 6.5 or above 8.0, it is likely that there is some particularity or irregularity, in which case it may be nondomestic waste. Despite the difference in the characteristics of the samples collected in the South Brasilia STP and North Brasilia STP, the results obtained from the field $\mathrm{pH}$ in the waste from the septage trucks were quite close, with medians of 7.10 and 7.05 , respectively.

Regarding the total alkalinity, $50 \%$ of the data from the septage samples collected from the trucks at the North Brasilia STP were concentrated between 146 and $304 \mathrm{mgCaCO}_{3} \cdot \mathrm{L}^{-1}$, with a median of $270 \mathrm{mg} \mathrm{CaCO}$. $\mathrm{L}^{-1}$. In turn, $50 \%$ of the data from the septage samples collected from trucks at the South Brasilia STP were concentrated between 268 and $370 \mathrm{mg} \mathrm{CaCO}$. $\mathrm{L}^{-1}$, with a median of 304 mg $\mathrm{CaCO}_{3} \cdot \mathrm{L}^{-1}$. It was also found that the total alkalinity was due exclusively to the presence of bicarbonates.

COD results in the septage samples showed medians of $4,230 \mathrm{mg} \cdot \mathrm{L}^{-1}$ at the South Brasilia STP and $457 \mathrm{mg} . \mathrm{L}^{-1}$ at the North Brasilia STP. This COD value for septage is lower than the average COD value obtained for decentralized sewage in Brazil, which is 734 mg.L-1 (SOUZA et al., 2019). One must question what makes the North Brasilia STP septage more diluted than sewage. 
Table 4: Descriptive statistics of the physical and chemical characterization of septage truck waste unloading at the two STPs in Brasilia.

\begin{tabular}{|c|c|c|c|c|c|c|c|c|c|c|c|c|c|c|c|}
\hline $\begin{array}{l}\text { Septag } \\
\text { e truck } \\
\text { waste } \\
\text { type }\end{array}$ & $\begin{array}{c}\text { Statistica } \\
\text { I } \\
\text { Paramet } \\
\text { ers }\end{array}$ & $\frac{T}{2}$ & 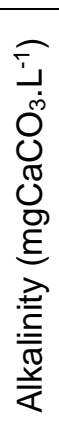 & 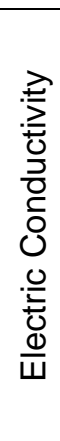 & 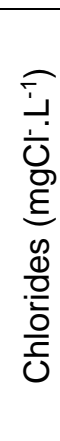 & 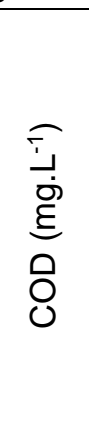 & 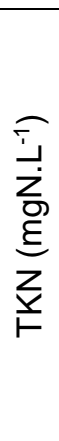 & 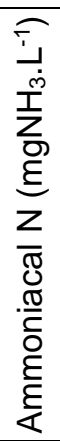 & 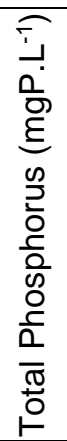 & 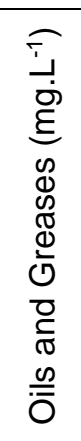 & 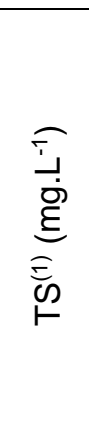 & 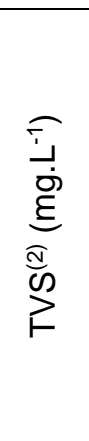 & 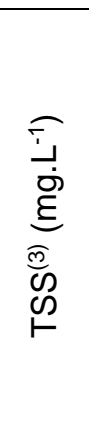 & 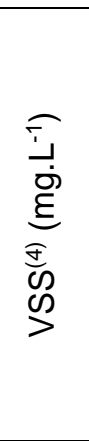 & 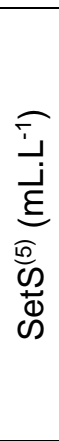 \\
\hline \multirow{9}{*}{$\begin{array}{l}\text { Septag } \\
\text { e } \\
\text { Trucks } \\
\text { unloadi } \\
\text { ng at } \\
\text { the } \\
\text { North } \\
\text { Brasilia } \\
\text { STP }\end{array}$} & $N^{(6)}$ & 16 & 15 & - & - & 14 & 10 & 13 & 15 & - & 14 & 13 & 12 & 9 & 16 \\
\hline & $\operatorname{Min} \mathrm{NO}^{(9)}$ & $\begin{array}{l}5.9 \\
0\end{array}$ & 79 & - & - & 108 & 23 & 11 & $\begin{array}{l}0 . \\
3\end{array}$ & - & 455 & 133 & 530 & 200 & 0 \\
\hline & $\begin{array}{l}\text { Max } \\
N^{(10)}\end{array}$ & $\begin{array}{l}7.9 \\
0\end{array}$ & $\begin{array}{l}84 \\
0\end{array}$ & - & - & $\begin{array}{l}6,93 \\
2\end{array}$ & $\begin{array}{l}11 \\
3\end{array}$ & 78 & 52 & - & $\begin{array}{l}45,5 \\
55\end{array}$ & $\begin{array}{l}3109 \\
7\end{array}$ & $\begin{array}{l}6,93 \\
0\end{array}$ & $\begin{array}{l}4,88 \\
9\end{array}$ & $\begin{array}{l}45 \\
0\end{array}$ \\
\hline & Mean & $\begin{array}{l}7.1 \\
5\end{array}$ & $\begin{array}{l}30 \\
1\end{array}$ & - & - & $\begin{array}{l}1,22 \\
0\end{array}$ & 74 & 47 & 13 & - & $\begin{array}{l}6,21 \\
1\end{array}$ & 4341 & $\begin{array}{l}2,20 \\
8\end{array}$ & $\begin{array}{l}1,46 \\
5\end{array}$ & 65 \\
\hline & $\begin{array}{l}\text { Quartile } \\
(75 \%)\end{array}$ & $\begin{array}{l}7.6 \\
0 \\
\end{array}$ & $\begin{array}{l}30 \\
4 \\
\end{array}$ & & & 830 & 88 & 57 & 19 & & $\begin{array}{l}1,84 \\
4\end{array}$ & 1325 & $\begin{array}{l}2,73 \\
8\end{array}$ & $\begin{array}{l}1,26 \\
0\end{array}$ & 51 \\
\hline & Median & $\begin{array}{l}7.1 \\
0\end{array}$ & $\begin{array}{l}27 \\
0\end{array}$ & - & - & 457 & 83 & 54 & 7 & - & $\begin{array}{l}1,02 \\
5\end{array}$ & 775 & 883 & 800 & 3 \\
\hline & $\begin{array}{l}\text { Quartile } \\
(25 \%)\end{array}$ & $\begin{array}{l}7.0 \\
0\end{array}$ & $\begin{array}{l}14 \\
6\end{array}$ & & & 365 & 58 & 32 & 2 & & 768 & 555 & 599 & 373 & $\begin{array}{l}0 . \\
3\end{array}$ \\
\hline & $\mathrm{SD}^{(7)}$ & $\begin{array}{l}0.6 \\
0\end{array}$ & $\begin{array}{l}23 \\
4\end{array}$ & - & - & $\begin{array}{l}1,85 \\
0\end{array}$ & 27 & 20 & 16 & - & $\begin{array}{l}12,8 \\
72\end{array}$ & 8816 & $\begin{array}{l}2,45 \\
9\end{array}$ & $\begin{array}{l}1,70 \\
0\end{array}$ & $\begin{array}{l}12 \\
6\end{array}$ \\
\hline & CV $(\%)^{(8)}$ & 8 & 78 & - & - & 152 & 36 & 43 & $\begin{array}{l}12 \\
3\end{array}$ & - & 207 & 203 & 111 & 116 & $\begin{array}{l}19 \\
4\end{array}$ \\
\hline \multirow{9}{*}{$\begin{array}{l}\text { Septag } \\
\text { e } \\
\text { Trucks } \\
\text { unloadi } \\
\text { ng at } \\
\text { the } \\
\text { South } \\
\text { Brasilia } \\
\text { STP }\end{array}$} & $\mathbf{N}^{(6)}$ & 9 & 9 & 6 & 5 & 3 & 3 & 3 & 2 & 8 & 9 & - & 9 & - & 9 \\
\hline & Min $\mathrm{NO}^{(9)}$ & $\begin{array}{l}6.6 \\
3\end{array}$ & $\begin{array}{l}23 \\
3\end{array}$ & $\begin{array}{l}58 \\
8\end{array}$ & 38 & $\begin{array}{l}3,80 \\
0\end{array}$ & 75 & 33 & 18 & 415 & $\begin{array}{l}1,27 \\
1\end{array}$ & - & 668 & - & 10 \\
\hline & $\begin{array}{l}\text { Max } \\
\mathrm{NO}^{(10)}\end{array}$ & $\begin{array}{l}7.4 \\
9\end{array}$ & $\begin{array}{l}38 \\
3\end{array}$ & $\begin{array}{l}84 \\
9\end{array}$ & 79 & $\begin{array}{l}5,46 \\
7\end{array}$ & $\begin{array}{l}13 \\
5\end{array}$ & 58 & 33 & $\begin{array}{l}4,77 \\
4\end{array}$ & $\begin{array}{l}4,40 \\
6\end{array}$ & - & $\begin{array}{l}2,86 \\
4\end{array}$ & - & 29 \\
\hline & Mean & $\begin{array}{l}6.9 \\
9 \\
\end{array}$ & $\begin{array}{l}33 \\
7\end{array}$ & $\begin{array}{l}79 \\
4\end{array}$ & 86 & $\begin{array}{l}4,49 \\
9\end{array}$ & $\begin{array}{l}10 \\
3\end{array}$ & 43 & 26 & $\begin{array}{l}1,75 \\
0\end{array}$ & $\begin{array}{l}2,66 \\
5\end{array}$ & - & $\begin{array}{l}1,86 \\
2 \\
\end{array}$ & - & 20 \\
\hline & $\begin{array}{l}\text { Quartile } \\
(75 \%)\end{array}$ & $\begin{array}{l}7.1 \\
6 \\
\end{array}$ & $\begin{array}{l}37 \\
0\end{array}$ & $\begin{array}{l}84 \\
9 \\
\end{array}$ & 79 & $\begin{array}{l}4,84 \\
9\end{array}$ & $\begin{array}{l}11 \\
6 \\
\end{array}$ & 48 & 29 & $\begin{array}{l}2,94 \\
8\end{array}$ & $\begin{array}{l}3,34 \\
6\end{array}$ & - & $\begin{array}{l}2,78 \\
9\end{array}$ & - & 24 \\
\hline & Median & $\begin{array}{l}7.0 \\
5 \\
\end{array}$ & $\begin{array}{l}30 \\
4 \\
\end{array}$ & $\begin{array}{l}73 \\
0 \\
\end{array}$ & 59 & $\begin{array}{l}4,23 \\
0 \\
\end{array}$ & 98 & 39 & 26 & 793 & $\begin{array}{l}2,77 \\
6 \\
\end{array}$ & - & $\begin{array}{l}1,85 \\
6 \\
\end{array}$ & - & 20 \\
\hline & $\begin{array}{l}\text { Quartile } \\
(25 \%)\end{array}$ & $\begin{array}{l}6.9 \\
2 \\
\end{array}$ & $\begin{array}{l}26 \\
8\end{array}$ & $\begin{array}{l}63 \\
4 \\
\end{array}$ & 59 & $\begin{array}{l}4,01 \\
5 \\
\end{array}$ & 86 & 36 & 22 & 664 & $\begin{array}{l}1,69 \\
3\end{array}$ & - & 982 & - & 13 \\
\hline & SD ${ }^{(7)}$ & $\begin{array}{l}0.4 \\
2 \\
\end{array}$ & $\begin{array}{l}10 \\
5\end{array}$ & $\begin{array}{l}23 \\
3\end{array}$ & 61 & 865 & 30 & 13 & 11 & $\begin{array}{l}1,63 \\
0 \\
\end{array}$ & $\begin{array}{l}1,08 \\
1\end{array}$ & - & 883 & - & 7 \\
\hline & CV $(\%)^{(8)}$ & 6 & 31 & 29 & 72 & 19 & 30 & 30 & 42 & 93 & 41 & - & 47 & - & 34 \\
\hline
\end{tabular}

(1) TS: Total Solids; (2) TVS: Total Volatile Solids; (3) TSS: Total Suspended Solids; (4) VSS: Volatile Suspended Solids; (5) SetS: Settleable Solids; (6) N: number of samples; (7) SD: Standard Deviation; (8) CV: Coefficient of Variation; (9) Min NO: minimum not outlier; ${ }^{(10)}$ Max NO: maximum not outlier. Source: the authors.

There was an almost tenfold difference in the COD concentrations in the truck samples in the two STPs. However, when verifying that the average COD in the North Brasilia STP septage is 1,220 mg. $\mathrm{L}^{-1}$, it is noted that there was a greater dispersion of results in the septage samples of the North Brasilia STP trucks, with a variation coefficient of $152 \%$. 
In truck samples at the South Brasilia STP, the average COD was $4,499 \mathrm{mg} \cdot \mathrm{L}^{-1}$, with a variation coefficient of only $19 \%$. The lower value for the variation coefficient in the COD of the South Brasilia STP septage samples may also have been provided by the smaller amount of data analysed. The average COD in the South Brasilia STP septage samples is more than three times the average in the North Brasilia STP septage samples. In general, the COD in septage is very variable, and can, in most cases, present values well above the sewage. Sometimes septage can present characteristics similar to sewage. The following factors can cause this high variability in COD values in septage among others: on-site facility cleaning frequency; socio-economic level of the served community; seasoning rainfall; groundwater level; and local soil permeability.

Regarding total phosphorus, the samples of the residues from the trucks that unloaded at the North Brasilia STP showed a median value of 7 $\mathrm{mg} \cdot \mathrm{L}^{-1}$. This value is equivalent to the average concentration of total phosphorus in decentralized sewage in Brazil, also $7 \mathrm{mg} . \mathrm{L}^{-1}$ (SOUZA et al., 2019). In turn, septage samples from trucks that unloaded at the South Brasilia STP showed a median phosphorus concentration of $26 \mathrm{mg} \cdot \mathrm{L}^{-1}$.

Regarding TKN and ammoniacal nitrogen, the median septage concentrations were $83 \mathrm{mg} . \mathrm{L}^{-1}$ and $54 \mathrm{mg} . \mathrm{L}^{-1}$, respectively, for the samples of the trucks that unloaded at the North Brasilia STP. In the septage of trucks unloading at the South Brasilia STP, the median concentration was 98 mg. $\mathrm{L}^{-1}$ of TKN and $39 \mathrm{mg} \cdot \mathrm{L}^{-1}$ of ammoniacal nitrogen. The TKN presented its largest portion in the form of organic nitrogen in the analysed samples, which is common in septage.

The median concentration of total solids in the waste samples from septage trucks collected at the North Brasilia STP was lower than the sample concentration of the South Brasilia STP trucks, 1,025 mg. $\mathrm{L}^{-1}$ and 2,776 mg. $\mathrm{L}^{-1}$, respectively. The same happened with the total suspended solids, whose medians were $883 \mathrm{mg} \cdot \mathrm{L}^{-1}$ for the North Brasilia STP and 1,856 mg. $\mathrm{L}^{-1}$ for the South Brasilia STP. Despite the high variability of septage characteristics in terms of total solids and total suspended solids, the median results were close to the median values found in the literature for random samples collected in septage trucks (BORGES, 2009; RATIS, 2009).

In median values, the total volatile solids corresponded to $76 \%$ of the total solids in the samples of the trucks that unloaded at the North
Brasilia STP, and the volatile suspended solids corresponded to $91 \%$ of the total suspended solids. In the analysed samples of the trucks of the South Brasilia STP, the total volatile solids corresponded to $57 \%$ of the total solids and the volatile suspended solids to $81 \%$ of the total suspended solids. These values indicate that the septage received at the North Brasilia STP had a fraction of organic matter higher than the septage received at the South Brasilia STP. These results also reveal that the septage of both STPs was partially digested or stabilized.

In relation to settleable solids, the median concentrations in the residues of the trucks of the North Brasilia STP and South Brasilia STP were 3 $\mathrm{mL} . \mathrm{L}^{-1}$ and $20 \mathrm{~mL} . \mathrm{L}^{-1}$, respectively. Furthermore, $50 \%$ of the data from the North Brasilia STP trucks were concentrated between $0.3 \mathrm{~mL} . \mathrm{L}^{-1}$ and 51 $\mathrm{mL} . \mathrm{L}^{-1}$ and $50 \%$ of the data from the South Brasilia STP samples were concentrated between $13 \mathrm{~mL}$. L1 and 24 mL.L-1.

The examination of oils and greases was performed only on the waste from septage trucks that were unloaded at the South Brasilia STP. The septage samples of the trucks had a median concentration of $793 \mathrm{mg} . \mathrm{L}^{-1}$ of oils and greases. When observing the results around the averages, there is a lack of normal data (Table 4). Of all the characteristics analysed in the samples of the South Brasilia STP, oils and greases were the ones with the highest variation coefficient. It was found that $50 \%$ of septage truck data remained between 664 and 2,948 mg. $\mathrm{L}^{-1}$ of oils and greases, with a maximum value of $4,774 \mathrm{mg} . \mathrm{L}^{-1}$.

Apart from $\mathrm{pH}$, most research shows the variability of results in septage samples for the characteristics analysed. The results of research carried out in Brazil (INGUNZA et al., 2009) have followed what has been observed worldwide (NARAYANA, 2020; TAYLER, 2018; STRANDE, RONTELTAP \& BRDJANOVIC, 2014) and shown the existence of great variability in the septage characteristics for practically all its constituents. The variation in the composition of this waste occurs mainly due to the septage detention time in the sewage treatment system and the technique used to remove this waste (MENESES et al., 2001; LEITE et al., 2006; INGUNZA et al., 2009; SANTOS, 2009; RATIS, 2009).

In addition to the septic tank and cesspool configuration, the removal technique employed, the frequency of removal of this residue, and the septage detention time inside the unit, the factors that also affect the septage characteristics are as 
follows: the climate, the mixture with groundwater when the groundwater level is high, the performance of the septic tank or cesspool, the user's habits, the characteristics of the water supply, the presence of waste disposers in the kitchen sink, and the presence of household chemicals (USEPA, 1999; MONTANGERO \& STRAUSS, 2004).

4.3 Characterization by origin and cleaning frequency of septage truck waste in the presence of grease trap residues

Of the greasy waste and septage collected,
$40 \%$ came from commercial grease traps, $8 \%$ from residential grease traps, $28 \%$ from residential septic tanks and cesspools, $12 \%$ from commercial septic tanks and cesspools, and $12 \%$ from septic tanks and cesspools from other sources, such as construction sites, as shown in Figure 4.

Figure 5 shows the frequency of cleaning the grease traps whose waste was brought by septage trucks and unloaded at the South Brasília STP. Most of the greasy residues received had a weekly cleaning frequency of the on-site sewage treatment units. However, grease trap waste was also received with monthly cleaning frequency and three times a week.

Figure 4: Declared origin of septage truck waste unloading at the South Brasilia STP in the presence of grease trap waste.

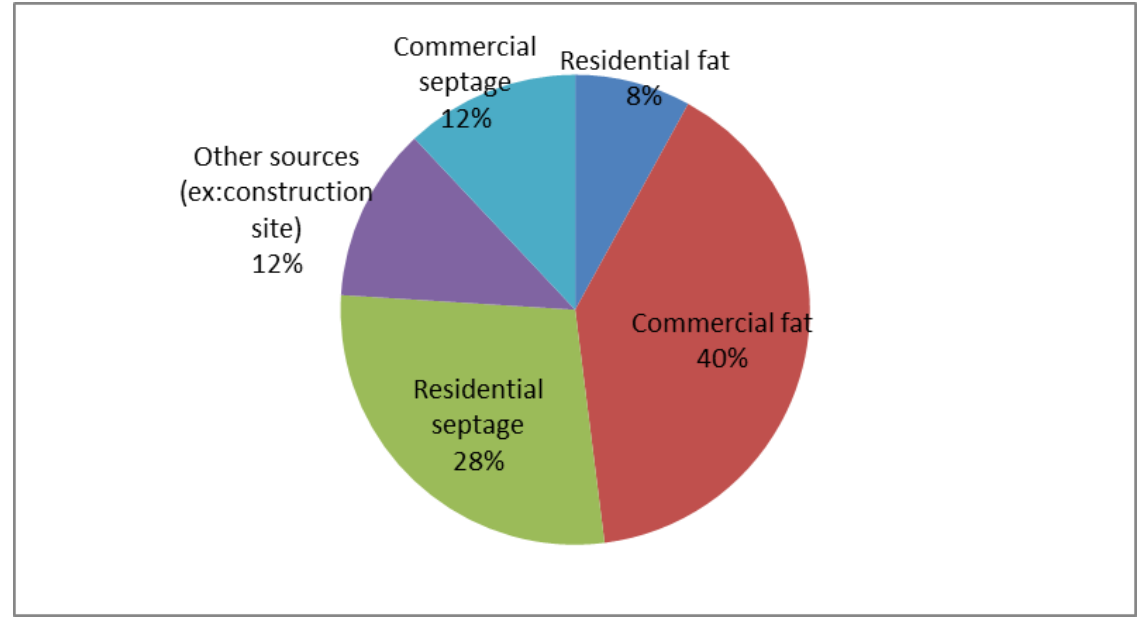

Source: the authors.

Figure 5 - Frequency of cleaning grease traps whose residues were brought by septage trucks and unloaded at the South Brasília STP.

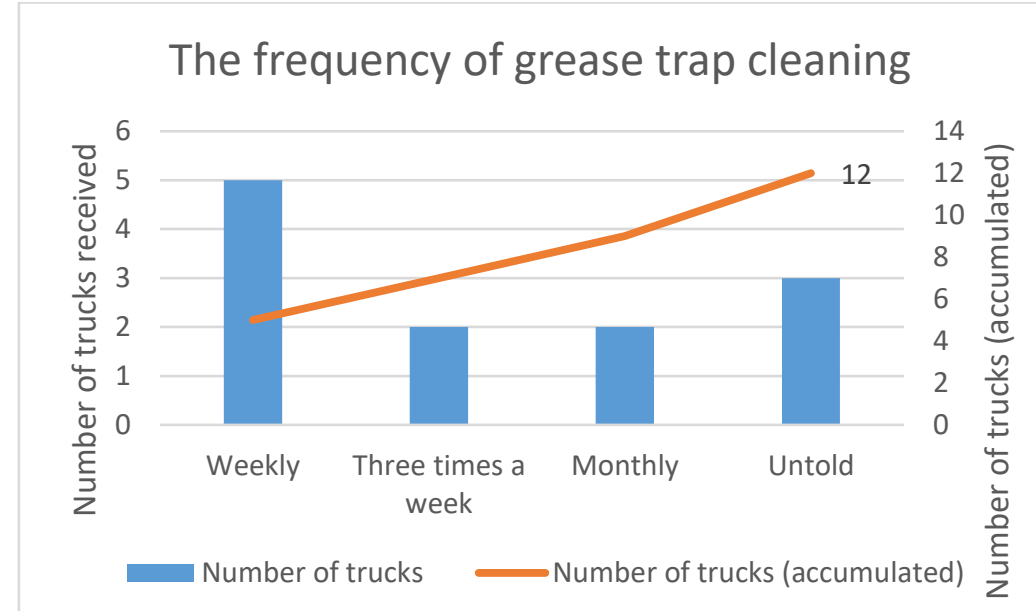

Source: the authors. 
4.4 Physical and chemical characterization of septage truck waste in the presence of waste from grease traps

Following the adopted methodology, samples from the mixture of greasy residues with septage were also characterized.

Table 5 shows the descriptive statistics of the results of the physical-chemical characterization of the samples of greasy residues mixed with septage.

It was observed that the greasy residues conferred lower $\mathrm{pH}$ median in the samples collected from mixtures between septage and fatty residues than the $\mathrm{pH}$ medians of the septage samples alone. The $\mathrm{pH}$ of mixtures between greasy waste and septage had a median of 6.27.

Regarding total alkalinity, the median concentration was $235 \mathrm{mg} \mathrm{CaCO} 3 \cdot \mathrm{L}^{-1}$. It is known that the presence of oily material and a high concentration of suspended solids can contribute to increased alkalinity (APHA, 2005). The dilution of greasy residues in the septage allowed measuring alkalinity, not ruling out possible interference in the results.

Table 5: Descriptive statistics on the characterization of samples collected from trucks at the South Brasilia STP (mixture of septage and greasy residues).

\begin{tabular}{|c|c|c|c|c|c|c|c|c|c|c|c|}
\hline $\begin{array}{c}\text { statistical } \\
\text { parameter } \\
\text { s }\end{array}$ & $\frac{T}{2}$ & 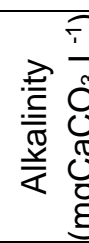 & 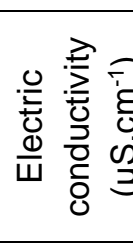 & 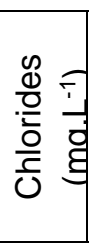 & $\begin{array}{l}\widetilde{I} \\
\dot{0} \\
\xi \\
0 \\
0 \\
0\end{array}$ & 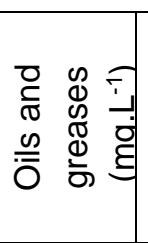 & 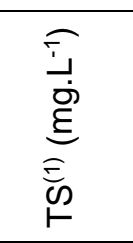 & 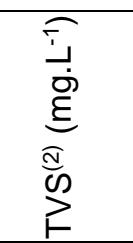 & 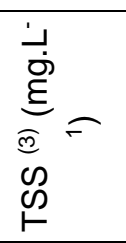 & 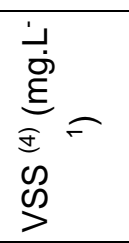 & 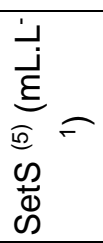 \\
\hline $\mathbf{N}^{(6)}$ & 6 & 6 & 6 & 6 & 5 & 6 & 6 & 6 & 6 & 6 & 6 \\
\hline $\operatorname{Min} \mathrm{NO}^{(9)}$ & $\begin{array}{c}6.1 \\
6\end{array}$ & 127 & 557 & 38 & 14,170 & 1,253 & 2,505 & 1,787 & 956 & 841 & 29 \\
\hline $\begin{array}{l}\text { Max } \\
\text { NO}^{(10)}\end{array}$ & $\begin{array}{c}6.6 \\
4\end{array}$ & 310 & 1,401 & 466 & 39,200 & 20,727 & 20,657 & 19,056 & 12,110 & 11,496 & 64 \\
\hline Mean & $\begin{array}{c}6.2 \\
3 \\
\end{array}$ & 302 & 1,023 & 274 & 25,088 & 9,024 & 10,630 & 8,349 & 7,017 & 5,957 & 61 \\
\hline $\begin{array}{l}\text { Quartile } \\
(75 \%)\end{array}$ & $\begin{array}{c}6.5 \\
5\end{array}$ & 310 & 1,334 & 425 & 34,960 & 20,721 & 13,124 & 10,620 & 10,425 & 7,857 & 64 \\
\hline Median & $\begin{array}{c}6.2 \\
7\end{array}$ & 235 & 1,107 & 283 & 22,280 & 4,942 & 10,704 & 6,676 & 7,064 & 5,253 & 55 \\
\hline $\begin{array}{l}\text { Quartile } \\
(25 \%)\end{array}$ & $\begin{array}{c}6.1 \\
6 \\
\end{array}$ & 161 & 634 & 151 & 17,640 & 1,562 & 6,087 & 4,644 & 4,483 & 4,446 & 36 \\
\hline $\mathrm{SD}^{(7)}$ & $\begin{array}{c}0.4 \\
0 \\
\end{array}$ & 232 & 358 & 166 & 10,297 & 9,344 & 6,307 & 6,212 & 4,030 & 3,679 & 34 \\
\hline CV $(\%)^{(8)}$ & 6 & 77 & 35 & 60 & 41 & 104 & 59 & 74 & 57 & 62 & 56 \\
\hline
\end{tabular}

(1) TS: Total Solids; (2) TVS: Total Volatile Solids; (3) TSS: Total Suspended Solids; (4) VSS: Volatile Suspended Solids; (5) SetS: Settleable Solids; ( ${ }^{(6)} \mathrm{N}$ : number of samples; (7) SD: Standard Deviation; (8) CV: Coefficient of Variation; ${ }^{(9)}$ Min NO: minimum not outlier; ${ }^{(10)}$ Max NO: maximum not outlier.

Source: the authors.

The median COD in the truck samples was $22,280 \mathrm{mg} \cdot \mathrm{L}^{-1}$, with a maximum value found of $39,200 \mathrm{mg} \cdot \mathrm{L}^{-1}$, with $50 \%$ of the results obtained being around 17,640 and $34,960 \mathrm{mg} \cdot \mathrm{L}^{-1}$.

Regarding the total solids results, the samples composed of the trucks had a median of 10,704 mg. L-1. A sample composed of trucks showed a maximum value of $20,657 \mathrm{mg} \cdot \mathrm{L}^{-1}$, with 19,056 $\mathrm{mg} \cdot \mathrm{L}^{-1}$ of total volatile solids $(92 \%$ of the total).
Another sample showed a minimum value of 2,505 mg. $\mathrm{L}^{-1}$ of total solids, with $1,787 \mathrm{mg} \cdot \mathrm{L}^{-1}$ of total volatile solids ( $71 \%$ of the total). The results of total solids obtained in the truck samples were $50 \%$ concentrated around 6,087 to $13,124{\mathrm{mg} . \mathrm{L}^{-1}}^{-}$. The median concentration of total suspended solids in the samples was 7,064 mg.L-1, with 5,253 mg. $\mathrm{L}^{-1}$ being volatile suspended solids (74\% of the total). The $50 \%$ of the total suspended solids 
results in the samples were concentrated between $4,483 \mathrm{mg} \cdot \mathrm{L}^{-1}$ and $10,425 \mathrm{mg} \cdot \mathrm{L}^{-1}$. The presence of greasy residues increased the organic matter in the samples analysed, as can be seen in the results of total volatile solids.

In characterizing the greasy residues from a residential condominium, Gasperi (2012) found values of $27,558 \mathrm{mg} \cdot \mathrm{L}^{-1}$ of total solids, $21,302 \mathrm{mg} . \mathrm{L}$ 1 of total volatile solids, $25,840 \mathrm{mg} \cdot \mathrm{L}^{-1}$ of total suspended solids, and $19,320 \mathrm{mg} \cdot \mathrm{L}^{-1}$ of total volatile suspended solids. That is, if only the greasy residues were analysed, the values found in the characterizations of the samples would be much higher. Their values were lower in this research due to their dilution with septage.

Of the results of settleable solids in the samples composed of trucks with greasy residues and septage, 50\% were concentrated between 36 and $64 \mathrm{~mL} . \mathrm{L}^{-1}$, with a median concentration of 55 $\mathrm{mL} . \mathrm{L}^{-1}$.

As for the test results of oils and greases on trucks, $50 \%$ were between 1,562 and $20,721 \mathrm{mg} . \mathrm{L}$ 1 , the median concentration of the samples was 4,942 mg. L-1 . When Gasperi (2012) characterized the residues coming from grease traps, he found a median concentration of oils and greases of 9,653 $\mathrm{mg} \cdot \mathrm{L}^{-1}$.

It was found that most of the results of the characteristics examined in the samples have wide ranges of variation. In terms of the coefficient of variation, the $\mathrm{pH}$ was the one with the lowest value, both in the waste samples from septage trucks containing only septage and in the samples with mixed greasy waste. In the samples with mixed greasy residues, oils and greases was the characteristic that presented the highest variation coefficient.

Analysing the results of the KolmogorovSmirnov and Shapiro-Wilk's tests, the lack of adjustment of the data to normal distribution (for $p$ $<0.05$ ) was confirmed, this behavior being a characteristic of all variables. It was also observed that the largest number of results was concentrated in the lower frequency classes, indicating the occurrence of asymmetry, which may have contributed to the increase in arithmetic means that are more influenced by extreme values.

The septage studies carried out in collaborative network research in Brazil (ANDREOLI, 2009) also showed this variability in septage samples, except for the $\mathrm{pH}$ parameter.

The adopted methodology of mixing fatty residues with septage made it possible to apply the analytical methods for liquid samples of wastewater and to simulate the reality existing in the septage discharges in the STPs in Brasília.

\section{CONCLUSIONS}

The results obtained confirmed the high variability in the physical and chemical characteristics of the septage, previously found in other studies in Brazil and in other countries. This makes it mandatory to survey these characteristics on a case-by-case basis before selecting and dimensioning a septage management proposal.

However, in several practical cases, it is impossible to wait for the results of a lengthy search. In these cases, the results of this research and similar ones serve to guide the planning of septage management and the design of treatment and conditioning units. The person in charge should use the septage characterization results to estimate limit values for optimistic and pessimistic scenarios.

In general, the septage samples collected from the trucks showed physical and chemical characteristics close to those of random samples collected in septage trucks found in the literature. There was also a lack of normality in the distribution of the results of physical and chemical characterization of waste from septage trucks. Of all the characteristics analysed in this research, oils and greases showed the highest variation coefficient in the samples with fatty residues, and the $\mathrm{pH}$ was the parameter that always presented the lowest variation coefficient.

As the $\mathrm{pH}$ of the septage was the characteristic that had the lowest variation, with an interval between 5.9 and 7.9 (average varying between 7.0 and 7.2), this fact allows the identification of the residues of the truck whose origin is not domestic through a simple and quick examination, and its discharge in STP may be refused.

The COD values in the septage samples revealed that this residue is rich in organic matter with an average value ranging between 1,220 and $4,499 \mathrm{mg} \cdot \mathrm{L}^{-1}$, for waste discharged by septage trucks at the two STPs in Brasilia (COD medians varied between 457 and 4,230 mg.L-1). The average COD of samples that had greasy residues mixed at septage was $25,088 \mathrm{mg} \cdot \mathrm{L}^{-1}$ (with a median of $22,280 \mathrm{mg} . \mathrm{L}^{-1}$ ). If the average expected COD for a decentralized raw sewage could be considered as $800 \mathrm{mg} . \mathrm{L}^{-1}$, this shows that these residues can be more concentrated than the decentralized raw sewage, between five and 30 times the 
concentration of decentralized raw sewage.

The values of oils and greases obtained in the septage samples were $1,750 \mathrm{mg} \cdot \mathrm{L}^{-1}$ (mean) and $793 \mathrm{mg} . \mathrm{L}^{-1}$ (median). The septage samples mixed with greasy residues revealed oil and grease values of $9,024 \mathrm{mg} \cdot \mathrm{L}^{-1}$ (mean) and $4,942 \mathrm{mg} \cdot \mathrm{L}^{-1}$ (median). With these high values, this waste, if released without treatment in the sewage system, can cause many problems to sewage collection and treatment.

The cleaning frequencies of the on-site sewage treatment facilities that generated the waste discharged by the septage trucks in the STPs of Brasilia varied widely. Few trucks brought septage with more than 1-year accumulation, which becomes a worrying factor, as in fact many of these exhausted septic tanks and cesspools are functioning only as septage holding tanks or passage tanks. The majority of the septage was slightly grey, characterizing a recent septage.

More than $70 \%$ of the septage was from residential origin. This helps to conclude that septage in the Federal District of Brazil has the same components as a common domestic sewer.

The presence of oils and greases in septage truck waste in the Federal District of Brazil is a major inconvenience, mainly due to the problems they can cause in sewage collection and treatment systems. Thus, the technologies for conditioning these residues must be designed considering a step of separating fats from the rest of the residues before they are treated with sewage in the STPS. These results are important for the design and dimensioning of septage reception and pretreatment equipment in sewage treatment plants in the Brazilian Federal District.

In view of the results obtained, a series of recommendations for future research can be made, such as focusing on the deleterious effects of septage discharges on the biological processes of sewage treatment, both aerobic and anaerobic. Also important is the study and development of simple and low-cost processes for removing oils and greases from septage, as well as the ways in which oils and greases originate in septage, and how to avoid the presence of oils and greases in septage.

\section{ACKNOWLEDGMENTS}

This research had the financial support of FINEP (Financier of Studies and Projects), an agency of the Brazilian government, through the Public Call MCT / MCIDADES / FINEP / Transversal Action -
Environmental Sanitation and Housing No. 06/2010.

\section{REFERENCES}

ANDRADE, C. F. Avaliação do tratamento do lodo de caminhões limpa-fossa e do percolado em sistemas alagados construídos de escoamento vertical. Dissertação de Mestrado (Evaluation of treatment of sludge from septage trucks and percolated liquid in vertical flow constructed wetlands. Masters Dissertation). Belo Horizonte, Minas Gerais, Brazil: Programa de Pós-graduação em Saneamento, Meio Ambiente e Recursos Hídricos da Universidade Federal de Minas Gerais. 116p. Available at: http://hdl.handle.net/1843/BUBD-9VNGVR. 2015.

ANDREOLI, C. V. (Editor) Lodo de fossas e tanques sépticos: caracterização, tecnologias de tratamento, gestão e destinação final (Septage: characterization, treatment technologies, management, and final destination). Curitiba, PR, Brazil: ABES - Associação Brasileira de Engenharia Sanitária e Ambiental. Programa de pesquisa em saneamento básico PROSAB. 383p. Available at: https://www.finep.gov.br/images/apoio-e-

financiamento/historico-deprogramas/prosab/prosab5 tema 6.pdf. 2009.

APHA Standard Methods for the Examination of Water and Wastewater. $21^{\text {st }}$ edition. Washington, D.C., U.S.A: APHA - American Public Health Association; AWWA - American Water Works Association; WPCF Water Pollution Control Federation. 2005.

BASSAN, M.; YIOUGO, L.; ZOELLIG, H.; MAHAMANE, I.; MBÉGUÉRÉ, M.; STRANDE, L. Characterization of faecal sludge during dry and rainy seasons in Ouagadougou, Burkina Faso. In: 36th WEDC INTERNATIONAL CONFERENCE: DELIVERING WATER, SANITATION AND HYGIENE SERVICES IN AN UNCERTAIN ENVIRONMENT. Nakuru, Kenya: Loughborough University. Proceedings. 7p. Available at:

https://repository.lboro.ac.uk/articles/Characterization o $\mathrm{f}$ faecal sludge during dry and rainy seasons in $\mathrm{Ou}$ agadougou Burkina Faso/9587864. 2013.

BLUNIER, P.; KOANDA, H.; KONÉ, D.; STRAUSS, M.; KLUTSÉ, A.; TARRADELLAS, J. (2004) Quantification des boues de vidange produites et vidangées. Exemple de la ville de Ouahigouya, Burkina Faso (Quantification of faecal sludge. Example of the city of Ouahigouya, Burkina Faso). In: FORUM DE RECHERCHE EN EAU ET ASSAINISSEMENT, CREPA. Ouagadougou, Burkina Faso: EAWAG. Proceedings. 8p. Available at: https://www.dora.lib4ri.ch/eawag/islandora/object/eawa g\%3A12126. 2004. 
BORGES, N. B. Caracterização e pré-tratamento de lodos de fossas e tanques sépticos. Dissertação de Mestrado (Characterization and pre-treatment of septage. Masters Dissertation). São Carlos, SP, Brazil: Escola de Engenharia de São Carlos da Universidade de São Paulo. 150p. Available at: https://www.teses.usp.br/teses/disponiveis/18/18138/td e-30032010-151857/publico/nayaraborges.pdf. 2009.

CAESB Companhia de Saneamento Ambiental do Distrito Federal. Relatório de indicadores de performance - Resultados 2018 (Performance indicators report - Results 2018). Brasília, DF, Brazil: CAESB. Available

at: https://www.caesb.df.gov.br/images/arquivos pdf/arquiv os Lai/indicadores desempenho2019.pdf. 2020.

CAMPOS, J. R.; POVINELLI, S. C. S.; AISSE, M. M.; SOUZA, M. A. A.; SAMWAYS, G.; ALEM SOBRINHO, P. Tratamento combinado de lodo de tanque séptico e de fossas com esgoto sanitário (Combined treatment of septage with sewage). In: Andreoli, C. V. (Coord). Lodo de fossas e tanques sépticos: caracterização, tecnologias de tratamento, gestão e destinação final (Septage: characterization, treatment technologies, management, and final destination). Curitiba, PR, Brazil: ABES - Associação Brasileira de Engenharia Sanitária e Ambiental. Programa de Pesquisa em Saneamento Básico - PROSAB. p. 181-282. Available at: https://www.finep.gov.br/images/apoio-e-

financiamento/historico-de-

programas/prosab/prosab5 tema 6.pdf. 2009.

CODEPLAN Companhia de Planejamento do Distrito Federal. PDAD-2013/2014 - Pesquisa Distrital por Amostragem de Domicílios (District Household Sample Survey). Brasília, DF, Brazil: CODEPLAN. Available at: http://www.codeplan.df.gov.br/wp-

content/uploads/2018/02/PDAD-Bras\%C3\%ADlia-

Plano-Piloto.pdf. 2014.

CODEPLAN Companhia de Planejamento do Distrito Federal. Estudo Urbano e Ambiental Consolidado do Distrito-Federal (Consolidated Urban and Environmental Study of the Federal District, Brazil). Brasília, DF, Brazil: CODEPLAN. Available at:

http://www.codeplan.df.gov.br/wp

content/uploads/2018/02/Estudo-Urbano-e-AmbientalConsolidado-do-Distrito-Federal-23-07-18.pdf. 2020.

DA SILVA, A. D. Avaliação do comportamento de uma estação piloto para recepção e pré-tratamento de resíduos de caminhões limpa-fossas. Dissertação de Mestrado (Evaluation of the behavior of a pilot plant for reception and pre-treatment of wastes from septage collect and transport trucks. Masters Dissertation). Brasília, DF, Brazil: Programa de Pós-Graduação em Tecnologia Ambiental e Recursos Hídricos. Publicação PTARH.DM-163/2014. Departamento de Engenharia Civil e Ambiental, Universidade de Brasília. 126p.
Available at: $\quad$ http://ptarh.unb.br/wpcontent/uploads/2017/03/Adriane Dias da Silva.pdf. 2014.

GASPERI, R. L. P. Caracterização de resíduos de caixa de gordura e avaliação como alternativa para o prétratamento. Dissertação de Mestrado (Characterization of grease traps residues and evaluation as an alternative for pre-treatment. Masters Dissertation). São Carlos, SP, Brazil: Escola de Engenharia de São Carlos da Universidade de São Paulo. 97p. Available at: https://www.teses.usp.br/teses/disponiveis/18/18138/td e-12062013-145456/pt-br.php. 2012.

HALALSHEH, M. M.; NOAIMAT, H.; YAZAJEEN, H.; CUELLO, J.; FREITAS, B.; FAYYAD, M. Biodegradation and seasonal variations in septage characteristics. Environmental Monitoring an Assessment. Vol. 172, p. 419-426. 2011.

IBGE Instituto Brasileiro de Geografia e Estatística. Pesquisa Nacional de Saneamento Básico - PNSB (National Survey of Basic Sanitation - PNSB). Brasília, DF, Brazil: IBGE - Instituto Brasileiro de Geografia e Estatística. 219p. Available at: https://biblioteca.ibge.gov.br/index.php/bibliotecacatalogo?view=detalhes\&id=283636. 2008.

INGUNZA, M. D. P. D.; ANDRADE NETO, C. O.; ARAÚJO, A. L. C.; SOUZA, M. A. A.; MEDEIROS, S. A.; BORGES, N. B.; HARTMANN, C. M. Caracterização física, química e microbiológica do lodo de fossa/tanque séptico (Physical, chemical, and microbiological characterization of septage). In: ANDREOLI, C. V. (Editor). Lodo de fossa e tanque séptico: caracterização, tecnologias de tratamento, gerenciamento e destino final. Curitiba, PR, Brazil: ABES - Associação Brasileira de Engenharia Sanitária e Ambiental. Programa de pesquisa em saneamento básico - PROSAB. p. 41-75. Available at: https://www.finep.gov.br/images/apoio-e-

financiamento/historico-de-

programas/prosab/prosab5 tema 6.pdf. 2009.

KRITHIKA, D.; THOMAS, A. R.; IYER, G. R.; KRANERT, M.; PHILIP, L. Spatio-temporal variation of septage characteristics of a semi-arid metropolitan city in a developing country. Environmental Science and Pollution Research International. V. 24, No 8. p. 70607076. doi:10.1007/s11356-016-8336-z. 2017.

LEITE, B. Z.; PEGORINI, E. S.; ANDREOLI, C. V.; ANDRADE, F. L. Caracterização e alternativas para disposição final de resíduos sépticos (Characterization and alternatives for the final disposal of septic waste). In: VIII SIMPÓSIO ÍTALO BRASILEIRO DE ENGENHARIA SANITÁRIA E AMBIENTAL. Anais. Fortaleza, CE, Brazil: ABES - Associação Brasileira de Engenharia Sanitária e Ambiental. 10p. 2006. 
LOPEZ-VAZQUEZ, C. M.; DANGOL, B.; HOOIJMANS, C. M.; BRDJANOVIC, D. Chapter 9 - Co-treatment of Faecal Sludge in Municipal Wastewater Treatment Plants. In: STRANDE, L.; RONTELTAP, M.; BRDJANOVIC, D. (Editors) Faecal Sludge Management - Systems Approach for Implementation and Operation. London, UK: IWA Publishing. ISBN: 9781780404738 (eBook). p. 177-201. Available at: https://www.eawag.ch/en/department/sandec/publicatio ns/fsm-book/. 2014.

MDR Ministério de Desenvolvimento Regional. SNIS Sistema Nacional de Informação em Saneamento. Diagnóstico dos serviços de água e esgoto - ano base 2018 (SNIS - National Sanitation Information System. Diagnosis of water and sewage services base year 2018). Brasília, DF, Brazil: MDR/SNS. Available at: www.snis.gov.br. 2020.

MENESES, C. G. R.; INGUNZA, M. P. D.; FARIAS, N. M. N.; CÂMARA, A. C. J. Caracterização físico-química e biológica dos resíduos de sistemas tipo tanque séptico-sumidouro da cidade de Natal (Physicalchemical and biological characterization of waste from septic tank-soakaway systems in the city of Natal). In: XXI CONGRESSO BRASILEIRO DE ENGENHARIA SANITÁRIA E AMBIENTAL. Anais. João Pessoa, PB, Brazil: ABES - Associação Brasileira de Engenharia Sanitária e Ambiental. 5p. 2001.

MONTANGERO, A.; STRAUSS, M. Faecal Sludge Treatment. Dübendorf, Switzerland: Eawag, Sandec Swiss Federal Institute of Aquatic Science \& Technology. $41 p$. Available at: https://www.susana.org/ resources/documents/default/ 2-406-strauss-montangero-2004-fs-treatment-sandecen.pdf. 2004.

NARAYANA, D. Septage and Faecal Sludge in Sewage Treatment Facilities: A Guide for Planners and Implementers. London, UK: IWA Publishing. 77p. Disponível em: https://doi.org/10.2166/9781789061277. 2020.

RAMOS, L. L. C. Diagnóstico e avaliação de coleta e disposição de lodo de fossa e de tanque séptico em Cuiabá-MT. Dissertação de Mestrado (Diagnosis and evaluation of septage collection and disposal in CuiabáMT. Masters Dissertation). Cuiabá, MT, Brazil: Programa de Pós-Graduação em Engenharia de Edificações e Ambiental, Universidade Federal de Mato Grosso. 87p. Available at: http://ri.ufmt.br/bitstream/1/521/1/DISS 2014 Lediane \%20Leslie\%20Campos\%20Ramos.pdf. 2014.

RATIS, A. N. F. A. Caracterização dos resíduos esgotados de sistemas de tratamento individual de esgotos domésticos de Natal. Dissertação de Mestrado (Characterization of exhausted residues from individual domestic sewage treatment systems in Natal. Masters Dissertation). Natal, Rio Grande do Norte, Brazil: Universidade Federal do Rio Grande do Norte, Programa de Pós-graduação em Engenharia Sanitária. 118 p. Available at: https://repositorio.ufrn.br/jspui/handle/123456789/15954 . 2009.

ROCHA, C.; SANT'ANNA, F. S. P. Regulamentação para despejos de caminhões limpa-fossas na ETE Jarivatuba, Joinville-SC (Regulation for septage truck dumps at the Jarivatuba STP, Joinville, SC, Brazil). In: XXIII CONGRESSO BRASILEIRO DE ENGENHARIA SANITÁRIA E AMBIENTAL. Anais. Campo Grande, MS, Brazil: ABES - Associação Brasileira de Engenharia Sanitária e Ambiental. 7p. 2005.

RODRIGUES, M. C.; AMORIM, F. F.; FREITAS, M. S.; ANDRADE, A. C.; SOUZA, M. A. A. Caracterização do lodo de fossas sépticas do Distrito Federal (Characterization of the Federal District septage). In: XXV CONGRESSO BRASILEIRO DE ENGENHARIA SANITÁRIA E AMBIENTAL. Anais. Recife, PE, Brazil: ABES - Associação Brasileira de Engenharia Sanitária e Ambiental. 10p. 2009.

SANTOS, Y. T. C. Caracterização do conteúdo de fossas sépticas e fossas na cidade de Natal. Dissertação de Mestrado (Characterization of the content of septic tanks and cesspools in the city of Natal. Masters Dissertation). Natal, Rio Grande do Norte, Brazil: Universidade Federal do Rio Grande do Norte, Programa de Pós-Graduação em Engenharia Sanitária. 205p. Available at: https://repositorio.ufrn.br/jspui/handle/123456789/15965 2009.

SOUZA, C. L.; DOS SANTOS, A. B.; SILVA, M. E. R.; AQUINO, S. F. Aspectos qualitativos de correntes de esgotos segregadas e não-segregadas (Qualitative aspects of segregated and non-segregated sewage streams). In: DOS SANTOS, A. B. (Editor) Caracterização, tratamento e gerenciamento de subprodutos de correntes de esgotos segregadas e não-segregadas em empreendimentos habitacionais (Characterization, treatment, and management of segregated and non-segregated sewage by-products in housing developments). Fortaleza, Ceará, Brazil: Imprece. p. 118-218. ISBN: 978-85-8126-190-4. Available at: http://www.finep.gov.br/images/apoio-efinanciamento/historico-de-

programas/prosab/06 112019 Prosab Tratamento d e Esgoto.pdf. pp. 118-218. 2019.

STRANDE, L.; RONTELTAP, M.; BRDJANOVIC, D. (Editors) Faecal Sludge Management - Systems Approach for Implementation and Operation. London, UK: IWA Publishing. ISBN: 9781780404738 (eBook). 403p. Available at: 
https://www.susana.org/en/knowledge-hub/resourcesand-publications/library/details/3591. 2014.

TAYLER, K. Faecal Sludge and Septage Treatment: A guide for low- and middle-income countries. Rugby, Warwickshire, UK: Practical Action Publishing Ltd. 349p. Available at: http://dx.doi.org/10.3362/ 9781780449869. 2018.

TIBCO STATISTICA Trial Version Download for Windows. Palo Alto, California, USA: TIBCO Software
Company. Available at: https://www.tibco.com/resources/productdownload/tibco-statistica-trial-download-windows. 2020.

USEPA United States Environmental Protection Agency. Decentralized systems technology fact sheet: septage treatment/disposal. Washington, Estados Unidos: USEPA. $8 p$. Available at: https://www3.epa.gov/npdes/pubs/septage.pdf. 1999. 